\title{
Consolidation works on sandstone monuments: A new approach
}

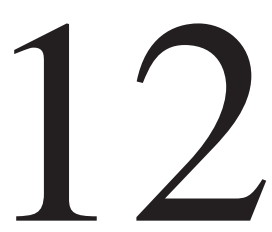

\author{
Marco Ludovico-Marques*, Carlos Chastre** \\ *Polytechnic Institute of Setúbal, Lavradio, Portugal; **CERIS, FCT, Universidade NOVA de
}

Lisboa, Lisbon, Portugal

\section{INTRODUCTION}

\subsection{STONE DEGRADATION PATTERNS AT ATOUGUIA DA BALEIA VILLAGE}

Portugal is the home of some very important buildings and monuments where natural stone is the predominant material, for example, in castles, churches, and palaces. Sandstones use is common in traditional buildings in western regions of Portugal (Peniche and Lourinhã) and in Algarve (Silves).

The International Council on Monuments and Sites-International Scientific Committee for Stone (ICOMOS-ISCS) [1] describes stone degradation patterns on monuments and ancient buildings. All of five families of ICOMOS-ISCS [1] patterns were found in the facades of the medieval monuments of Atouguia da Baleia, in Peniche [2]: crack and deformation; detachment; features induced by material loss, discoloration, and deposits; biological colonization.

All porous building materials are reached by salt weathering effects near the shoreline and in desert environments. The seawater is the source of sodium chloride salt, absorbed by capillarity from the water table below foundations and by salt spray that reaches building facades. Salt effect on porous building materials is visible even at a distance of about $3-5 \mathrm{~km}$ from the coast, besides the decrease of circa $30 \%-50 \%$ on chlorides concentration in total deposition [3]. The oldest known reference about salt effects on buildings in desert environments belongs to Herodotus and was written in fifth century before common era (BCE). The Greek historian reported that salts injured the pyramids, cited in Ref. [4]. Lucas cited in Ref. [5] referred to sodium chloride as playing the most important leading role in the majority of conservation and restoration works on sandstones and limestones of dry environments — namely, in Egypt—followed by sulfates, carbonates, and nitrates. A recent report indicates general salt damage occurrence on the buildings of the Jazirat Al Hamra area in United Arab Emirates [6], a town located near the shoreline and in a desert environment. 
The effects of salt weathering include cracks and deformation, detachment, and features induced by material loss. Alveolization or honeycomb weathering is visible on the medieval St. Leonard's church $[2,7]$ and is an outstanding example of the latter stone-weathering pattern. Dimension blocks of St. Leonard's church show widespread cavities connected to each other with several of them more than $10 \mathrm{~cm}$ long and deep (Fig. 12.1). Evans and Rodriguez-Navarro et al. [4, 8] reported the close relationship between alveolization and the mechanisms of degradation by salts and wind.

The sea vicinity explains the intense and widely spread alveolization in St. Leonard's sandstone building blocks. In the Middle Ages there was a harbor at Atouguia da Baleia and St. Leonard's church was near the shoreline for about the first half of its almost 800 years of history. Sodium chloride salts were absorbed by capillarity from seawater and even nowadays salt mist reaches the monument. Efflorescences - a type of discoloration and deposits features-are not visible in monuments facades. However, chemical analyses carried out in dissolution waters from a few and very small sandstone samples collected from St. Leonard's facades revealed that chlorides predominate over sulfates [2].

Even today's climate parameters allow crystallization and dissolution cycles of salts on stone buildings.

\subsection{CONSOLIDATION TREATMENTS}

The more porous types of sandstone building stones are due to higher degrees of weathering and can be treated with stone consolidants. Silanes are organic compounds

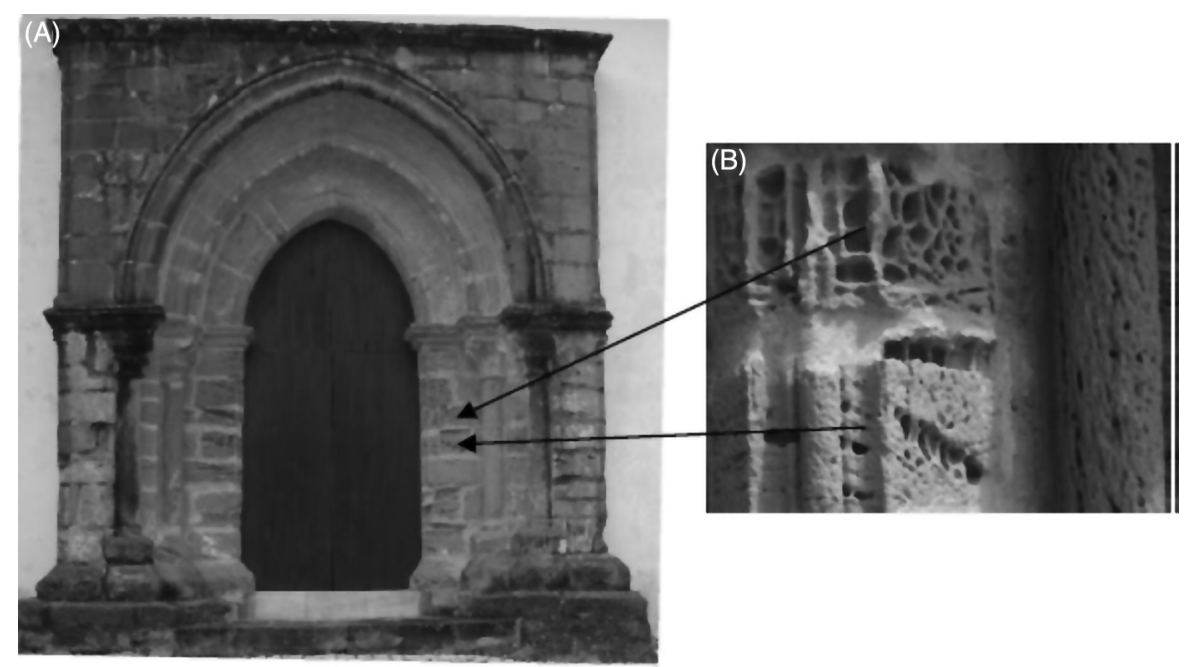

FIGURE 12.1 South façade and vault of St. Leonardo's church.

(A) View of vault, and (B) alveolization patterns in blocks and column in the right side below the vault. 
being methyltrimethoxysilane (MTMOS) and tetra-ethoxysilane (TEOS) the more used because of their consolidation effect on stones and its commercial availability. A condensation reaction occurs inside stone voids to give a silicone polymer, after a hydrolysis reaction responsible to form silanols. Silanes in stone consolidation were used from the late 19th century to the beginning of the 21st century. Better results were obtained in sandstone treatments with ethyl silicate applications than on other stones.

The most suitable treatment procedures should be selected according to each stone, its dimensions, shape, and weathering grade, with the goal being the impregnation front to reach deeply into the sound stone allowing time enough for the evaporation of the solvents. The main application methods of the consolidating products on stone surfaces are the following: brushing and spraying, capillarity, immersion, and immersion under vacuum.

If immersion is set aside, all other methods can be applied on all building elements. Immersion is more appropriate to carry out treatments on removed single blocks or elements of stone art as sculptures. A better consolidation effect can be obtained by brushing and, in particular, spraying the stone's surface, because it is followed by a suitable polyethylene cover that allows impregnation and continuous longer action. The capillarity method involves a reservoir with the consolidating product connected to a cotton poultice on the stone surface, also with a polyethylene cover to avoid evaporation of the solvent as long as impregnation occurs.

The new approach method of application used in this study is based in a Karsten pipe and it is a variation of RILEM's water absorption under low-pressure test procedure [9]. The Karsten pipe is a glass tube fixed on the stone-wall surface with a removable and not harmful putty. The vertical pipe is filled with consolidating product instead of water, through the upper opening of the tube upward to the top graduation. The full pipe has $4 \mathrm{~cm}^{3}$ of volume and a total height of $0.098 \mathrm{~m}$ between the center of the application and the upper graduation, corresponding to a pressure of $0.098 \rho$ and being $\rho$ the unit weight of the product. The product level in the pipe should be kept constant by adding continuously this product to maintain the pressure on the stone surface.

Scientific conservation plays a major role in a sustainable cultural heritage preservation. Suitable conservation actions optimize the environmental value of the cultural resources in a long-term point of view and have an important contribution to the creation of a sustainable habitat.

\section{EXPERIMENTAL}

\subsection{MINERALOGICAL CHARACTERIZATION}

There are four varieties of sandstones found in monuments $[2,7]$ and they are classified as lithic arkose with carbonate cement [10]. The A and B varieties have about $34 \%-40 \%$ carbonates and 30\%-32\% quartz. The $\mathrm{C}$ and $\mathrm{M}$ varieties have around $20 \%-25 \%$ carbonates and $40 \%-51 \%$ quartz. In this chapter only the results of $\mathrm{C}$ and 
M varieties are shown because these varieties exhibit values of physical properties representative of the more weathered sandstones in monuments.

All these varieties have about $4 \%-6 \%$ of mica minerals. The average size of grains of quartz and feldspar in the $\mathrm{A}$ and $\mathrm{B}$ varieties ranges from 0.1 to $0.13 \mathrm{~mm}$, and in $C$ and $M$ varieties the average size ranges between 0.15 and $0.24 \mathrm{~mm}$. $C$ and $\mathrm{M}$ sandstones are medium to fine grained, whereas $\mathrm{A}$ and $\mathrm{B}$ sandstones are generally fine-grained.

\subsection{PREPARATION OF SPECIMENS}

The samples were extracted from stone masonry walls close to the built heritage, accounting their similarity in terms of appearance, mineralogical composition, texture, and structure, to the stone in the monuments.

Prismatic and cubic specimens with $50 \times 50 \mathrm{~mm}^{2}$ of cross section corresponding to a height-to-length ratio of $2: 1$, respectively, were randomly cut in sandstones of $\mathrm{C}$ and $\mathrm{M}$ varieties.

\subsection{CONSOLIDATING PRODUCTS AND THEIR APPLICATIONS}

These studies of conservation intervention encompasses the treatment of stones and were carried out in a laboratory environment and in the monument to evaluate the viability of two ethyl silicate consolidation applications on stones. TG and $\mathrm{R}$ were selected in this experimental work because of their commercial availability and reasonable costs.

The manufacturer $\mathrm{X}$ produces $\mathrm{TG}$ in a single component. This product has $0.95 \pm 0.02 \mathrm{~g} / \mathrm{cm}^{3}$ at $25^{\circ} \mathrm{C}$ and after the evaporation of the solvents at $20^{\circ} \mathrm{C}$ and $60 \%$ of RH a dry residue of $34 \%$ is allowed to form.

$\mathrm{R}$ is manufactured by $\mathrm{Y}$ in a single component that reports a unit weight of $0.83 \pm 0.02 \mathrm{~g} / \mathrm{cm}^{3}$. A dry residue of $17 \%$ is allowed to form after the evaporation of the solvents at $20^{\circ} \mathrm{C}$ and $60 \%$ of $\mathrm{RH}$.

The consolidation procedures were followed on $5 \mathrm{~cm}$-long cubic samples. The products were applied step by step by immersion and capillarity procedures over all stone mass, according to Ludovico-Marques [2]. The amounts of absorbed products were around $3 \%$ of mass content in $\mathrm{C}$ variety and $5 \%$ in variety $\mathrm{M}$ sandstones. Then, the samples were placed at room temperature and RH of Geotechnics Laboratory in Civil Engineering Department of Universidade Nova de Lisboa for the drying process. A dry residue of about $40 \%$ of TG and $25 \%$ of R remained in the sandstone samples after evaporation of the solvents during 8 weeks. The capillarity procedure was followed on specimens used to carry out drying tests. Capillarity height reached $2.5 \mathrm{~cm}$ and the amounts of absorbed products were around $1 \%$ of mass content on variety $\mathrm{C}$ and circa $3 \%$ of mass content on variety $\mathrm{M}$.

$\mathrm{R}$ was applied by Karsten pipe method on sandstone block at right side of south portal below the vault and was absorbed an amount of $2.5 \mathrm{~g}$, that is, $1.1 \mathrm{~kg} / \mathrm{m}^{2}$ per application. 


\subsection{PHYSICAL TESTS}

Physical tests were carried out to determine porosity and density on sandstone samples following the recommendations of RILEM [9] and EN 1936 [11]. These four varieties samples exhibit similar values of porosity of the historical building stones, ranging from $3.6 \%$ (variety $\mathrm{A}$ ) to $12.7 \%$ (variety $\mathrm{C}$ ) and $18.5 \%$ (variety $\mathrm{M}$ ).

Ludovico-Marques [2] presented the pore size distribution of sandstone varieties $\mathrm{C}$ and $\mathrm{M}$ obtained by mercury intrusion porosimetry. Microporosity settled as the percentage of pores radii lower than $7.5 \mu \mathrm{m}$ [12], is $85 \%-95 \%$ in variety $\mathrm{C}$ and $75 \%-81 \%$ in variety $\mathrm{M}$.

Drying tests were carried out on sandstone cubic samples of varieties $\mathrm{C}$ and $\mathrm{M}$ before and after treatments, following the recommendations of NORMAL 29/88 and RILEM $[9,13]$ in a laboratory environment of $20 \pm 2{ }^{\circ} \mathrm{C}$ and $55 \pm 10 \%$ of RH. Drying was only allowed on the top face of specimens because the other faces were sealed with an epoxy resin impermeable to water.

Drying index (DI) of NORMAL 29/88 [13] characterizes the drying behavior from experimental curves of time dependent of the water content $\left(f\left(Q_{i}\right)\right)$ as a percentage of the dry mass at the ending time of drying $\left(t_{f}\right)$. Being the initial water content $\left(Q_{\max }\right)$ and the initial time $\left(t_{0}\right)$, the drying index (DI) is given through the following equation:

$$
\boldsymbol{D I}=\left(\int_{t_{0}}^{t_{f}} \boldsymbol{f}\left(\boldsymbol{Q}_{i}\right)\right) /\left(\boldsymbol{Q}_{\max } \boldsymbol{t}_{f}\right)
$$

Water absorption under low-pressure test procedure [9] was carried out on prismatic and cubic sandstone samples. A removable and nonharmful putty fixes the Karsten tube on the specimen surface. The vertical tube is filled with water through the top opening of the pipe up to the top graduation " 0. ." The tube has a total measuring height of $0.098 \mathrm{~m}$ and the volume of $4 \mathrm{~cm}^{3}$. The measurement apparatus for vertical surfaces was used in tests performed on sandstone masonry of South portal (Fig. 12.2). The results in this study are represented in the form of a water absorption graph (mass of water per unit area of absorption) in function of the square root of time. The slope of the linear part of the test curve gives the water absorption coefficient.

\subsection{MECHANICAL TESTS}

The uniaxial compression tests on the sandstones used a Seidner servo-controlled press, model 3000D, with load capacity up to $3000 \mathrm{kN}$ and a piston stroke of $50 \mathrm{~mm}$ [2]. The tests were carried out under axial displacement control at a rate of $10 \mu \mathrm{m} / \mathrm{s}$ on cubic specimens of varieties $\mathrm{C}$ and $\mathrm{M}$.

The Drilling Resistance Test Measurement System (DRTMS) herein used belongs to the Laboratory of Stone of Conservation and Restoration Department at Universidade Nova de Lisboa and was produced by Sint Technology, Srl. The 


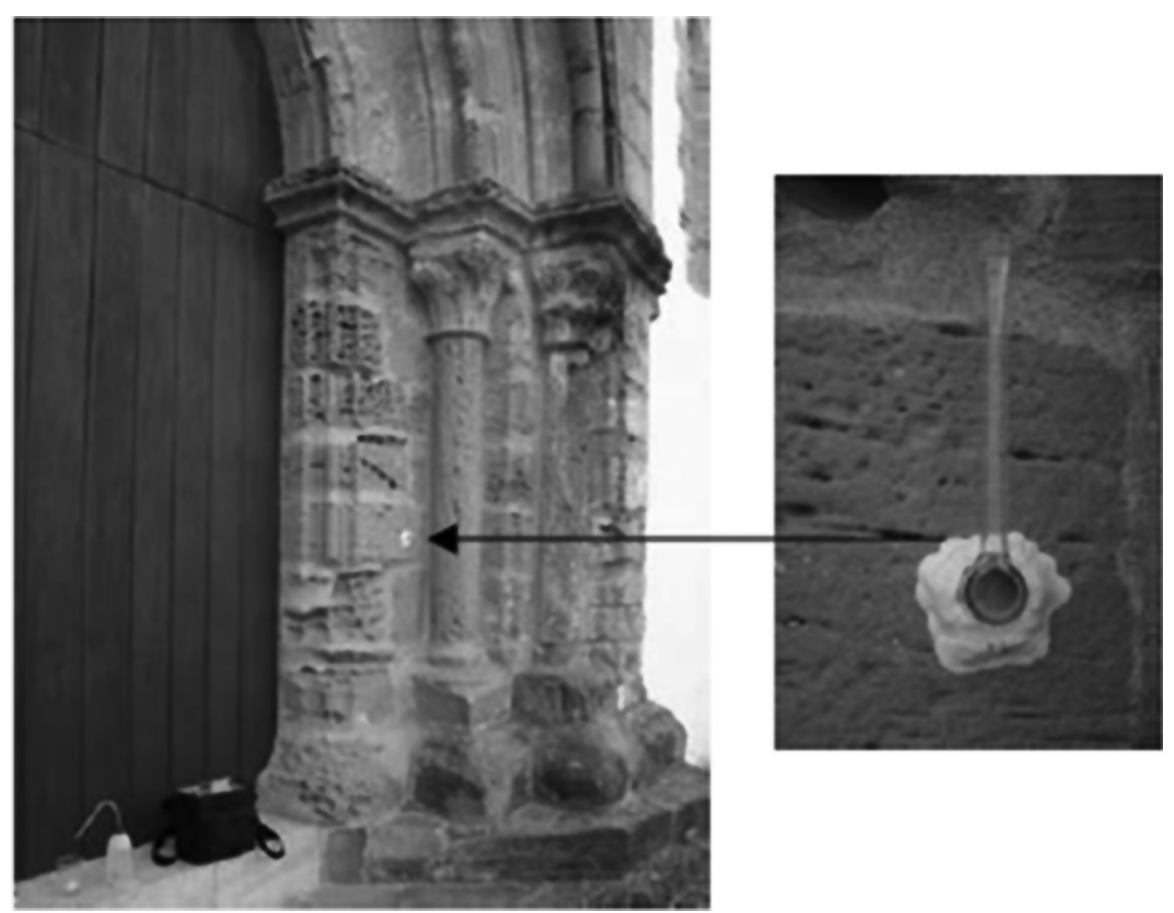

FIGURE 12.2 Water absorption under low pressure T3 test (Karsten pipe method).

Carried out on the south façade of St. Leonardo's church on a block on the right side below the vault.

DRTMS is a portable micro drilling device that measures the drilling strength using a load cell on a drill bit with $5 \mathrm{~mm}$ in diameter and a triangular tip. Diaber tungsten drill bits used allow a maximum drill hole depth up to $25 \mathrm{~mm}$. An advancing rate of $20 \mathrm{~mm} / \mathrm{min}$ and a speed rotation of $200 \mathrm{rpm}$ were the drilling parameters adopted according to Ludovico-Marques [2]. The tests were performed on sandstone samples and on a block of South façade of St. Leonardo's church in the right side below the vault, before and after consolidation treatments (Fig. 12.3).

Drill holes with $25 \mathrm{~mm}$ of depth were carried out on opposite faces of $\mathrm{M}$ sandstone samples in order to check full impregnation depth of consolidation treatments with $\mathrm{R}$ and TG products, from top faces into down faces and from down faces upward top faces.

\subsection{DURABILITY ASSESSMENT TESTS}

Crystallization tests by total immersion were carried out following RILEM V.1a, b, V.2 [9] and NP EN 12370 [14], replacing sodium sulfate solutions by sodium chloride solutions. These standard experimental procedures indicate total immersion of stone samples in $10 \%-14 \%$ salt solution for $2 \mathrm{~h}$ at room temperature at about $20^{\circ} \mathrm{C}$. 


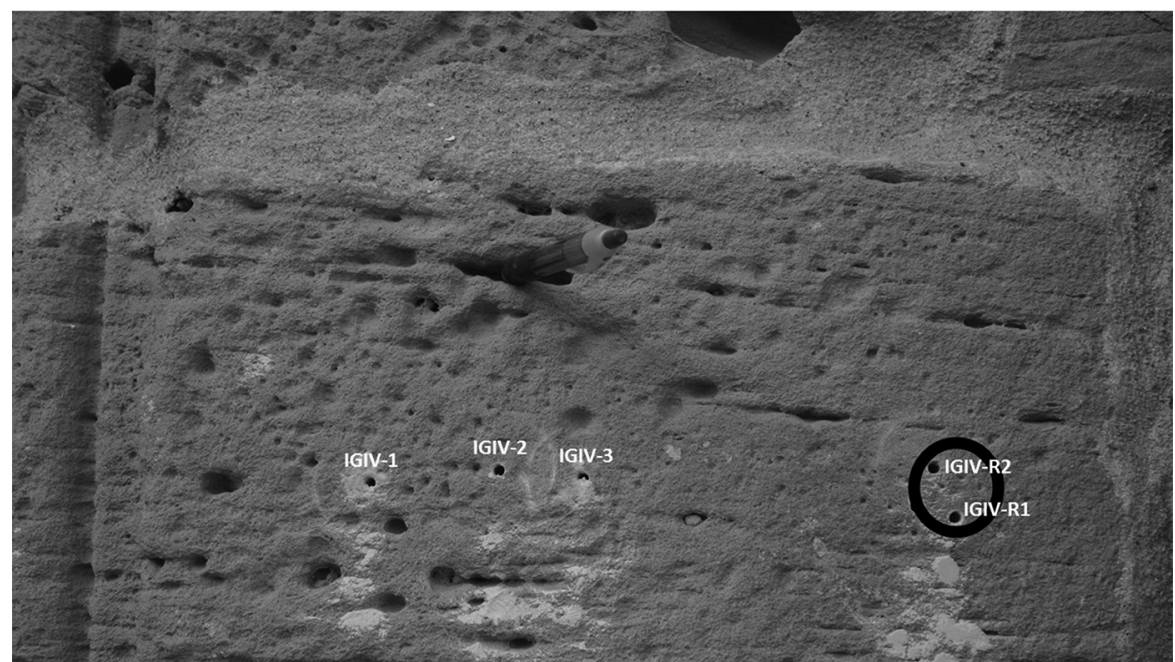

FIGURE 12.3 Tests carried out with DRTMS on a block from the South Façade of St. Leonardo's church.

Shown on the right side below the vault, before treatments (IGIV-1, IGIV-2, IGIV-3) and after treatments (IGIV-R1, IGIV-R2).

After immersion the test cubes should be removed from the solution and dried in an oven for at least $16 \mathrm{~h}$ until they reached constant weight at about $60^{\circ} \mathrm{C}$ and then cooled to room temperature again, at about $20^{\circ} \mathrm{C}$.

Salt-crystallization-dissolution aging tests were carried out in an automatic aging chamber prototype, developed from a modified oven. The prototype control system once programmed allows automatic immersion of the cubic stone samples in several trays. After some time of immersion, salt solutions return to bottom reservoirs. Then the oven reaches $60 \pm 2^{\circ} \mathrm{C}$ for several hours and stops at the scheduled time. After this step cooling begins at $20 \pm 2^{\circ} \mathrm{C}$ for the desired time. This aging chamber develops salt-crystallization cycles inside stone pores by heating and salt dissolution after cooling by immersion with salt solutions. Each tray can contain 30 cubic samples with $5 \mathrm{~cm}$ length over a designed support in the bottom.

The prototype control system was programmed to carry out 60 cycles of $2 \mathrm{~h}$ of samples immersion in a sodium chloride solution at $10 \%(\mathrm{~W} / \mathrm{W}), 20 \mathrm{~h}$ of heating (salt crystallization), and $2 \mathrm{~h}$ of cooling.

The stone samples after the aging cycles were washed with deionized waters until salt-removing waters reached a concentration of about $1 \mathrm{ppm}$ of ions in an hour. After this, the stone samples were dried in an oven at $60^{\circ} \mathrm{C}$ and then kept in a dessicator vessel at $20^{\circ} \mathrm{C}$.

RILEM's water absorption under low-pressure tests were also carried out on the sandstone cubic samples of varieties $\mathrm{C}$ and $\mathrm{M}$ before and after salt crystallizationdissolution aging tests, following the recommendations of RILEM [9]. 


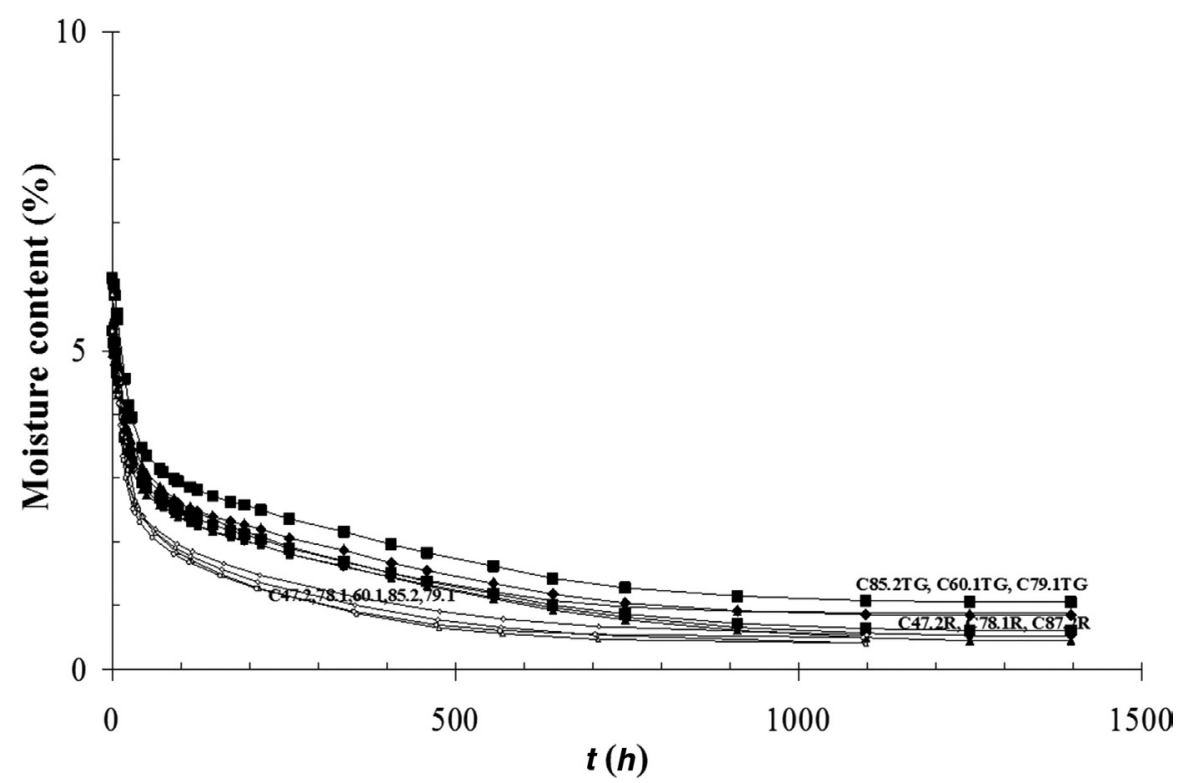

FIGURE 12.4 Drying tests on cubic specimens of $\mathrm{C}$ variety.

Before (empty smaller dots) and after treatments (full larger dots).

Damage assessment by weighing the remaining mass of stone samples during aging tests to obtain mass loss in percentage was done by recommendations of RILEM V.1a, b, V.2 [9] and EN 12370 [14] standards.

The uniaxial compression tests were also carried out on sandstone samples before and after salt-crystallization artificial aging tests.

\section{ANALYSIS OF THE RESULTS}

\subsection{PHYSICAL BEHAVIOR}

Fig. 12.4 highlights the consolidation effect on drying curves of $\mathrm{C}$ variety cubic samples. The results shown in Tables 12.1 and 12.2 reveal a significant increase in average drying index (DI) values after treatments of $71 \%$ on TG and $47 \%$ on R, respectively. The lower values of DI indicate a faster physical mechanism of drying. A significant increment of DI values is representative of a harmful behavior of consolidation effect.

Table 12.3 and Fig. 12.5 illustrate close values of coefficient of absorption $k$ on the monument block to those obtained on $\mathrm{C}$ sandstone specimens, indicating a physical match between the block stone and the $\mathrm{C}$ variety around an average value of porosity of $12.7 \%$. 
Table 12.1 Drying Index Values Obtained on C Sandstone Specimens Before Treatments

\begin{tabular}{l|l|l|l} 
Varieties & $\begin{array}{l}\text { Specimens } \\
\text { (cubes) }\end{array}$ & Drying Index & Average \pm SD (CV \%) \\
\hline \multirow{4}{*}{ C60.1 } & DI & Drying Index \\
C85.2 & 0.18 & \\
C79.1 & 0.15 & \\
& C78.1 & 0.16 & $0.20 \pm 0.07(35.00)^{\star}$ \\
& C47.2 & 0.18 & $0.17 \pm 0.01(5.88)$ \\
\hline & C87.2 & 0.18 & \\
\hline
\end{tabular}

*With the higher value.

Table 12.2 Drying Index Values Obtained on Treated C Sandstone Specimens

\begin{tabular}{l|l|l|l}
$\begin{array}{l}\text { Consolidating } \\
\text { Product }\end{array}$ & $\begin{array}{l}\text { Specimens } \\
\text { (cubes) }\end{array}$ & Drying Index & Average \pm SD (CV \%) \\
TG & C85.2 & 0.29 & DI \\
& C79.1 & 0.29 & \\
& C60.1 & 0.28 & $0.29 \pm 0.01(3.45)$ \\
$\mathrm{R}$ & $\mathrm{C} 47.2$ & 0.25 & \\
& $\mathrm{C} 78.1$ & 0.24 & $0.25 \pm 0.01(4.00)$ \\
\hline
\end{tabular}

The consolidation effect on water absorption under low-pressure curves is highlighted in Fig. 12.6. The coefficient of absorption decreased between mean values of $7.9 \mathrm{~kg} / \mathrm{m}^{2} / \mathrm{Vh}$ on nontreated specimens and, respectively, $5.8 \mathrm{~kg} / \mathrm{m}^{2} / \mathrm{Vh}$ on TG and $4.5 \mathrm{~kg} / \mathrm{m}^{2} / \sqrt{\mathrm{h}}$ on $\mathrm{R}$, that is, a reduction of $27 \%$ in the former and $43 \%$ in the latter.

The consolidation effect on drying curves of $M$ variety cubic samples is highlighted in Fig. 12.7 for TG and Fig. 12.8 for R. The results shown in Table 12.4 revealed a minor increase in average drying index (DI) values after the treatments of, respectively, $20 \%$ on TG and $10 \%$ on R. A minor increment of DI values is not representative of a harmful behavior of consolidation effect. A faster physical mechanism of drying is indicated by lower values of DI.

The consolidation effect on water absorption under low-pressure curves is highlighted in Fig. 12.9. Table 12.5 illustrates the decreasing of the coefficient of absorption between mean values of $24.0 \mathrm{~kg} / \mathrm{m}^{2} / \mathrm{J}_{\mathrm{h}}$ on nontreated specimens and, respectively, $12.6 \mathrm{~kg} / \mathrm{m}^{2} / \sqrt{\mathrm{h}}$ on $\mathrm{TG}$ and $20.9 \mathrm{~kg} / \mathrm{m}^{2} / \sqrt{\mathrm{h}}$ on $\mathrm{R}$, that is, a reduction of circa $48 \%$ in the former and $13 \%$ in the latter. 
Table 12.3 Water Absorption Coefficient k Obtained on C Sandstone Specimens and on Monument Block (T3 Test)

\begin{tabular}{|c|c|c|c|}
\hline Variety & Specimens & $\begin{array}{l}\text { Water Absorption } \\
\text { Coefficient } k\left(\mathrm{~kg} / \mathrm{m}^{2} / \sqrt{\mathrm{h}}\right)\end{array}$ & $\begin{array}{l}\text { Water Absorption } \\
\text { Coefficient } k\left(\mathrm{~kg} / \mathrm{m}^{2} / \sqrt{ } \mathrm{h}\right)- \\
\text { Average } \pm \text { SD }(\mathrm{CV} \%)\end{array}$ \\
\hline C & $\begin{array}{l}\text { CP1 } \\
\text { CP1p } \\
\text { CP4 } \\
\text { CP4p } \\
\text { CP12 } \\
\text { CP12p } \\
\text { CP14 } \\
\text { CP14p } \\
\text { T3 }\end{array}$ & $\begin{array}{l}8.3 \\
7.4 \\
8.7 \\
8.8 \\
8.7 \\
6.8 \\
5.3^{\star} \\
6.7 \\
6.0\end{array}$ & $\begin{array}{l}7.6 \pm 1.3(17.1)^{\star} \\
7.9 \pm 0.9(11.4) \\
-\end{array}$ \\
\hline
\end{tabular}

*With the lower value.

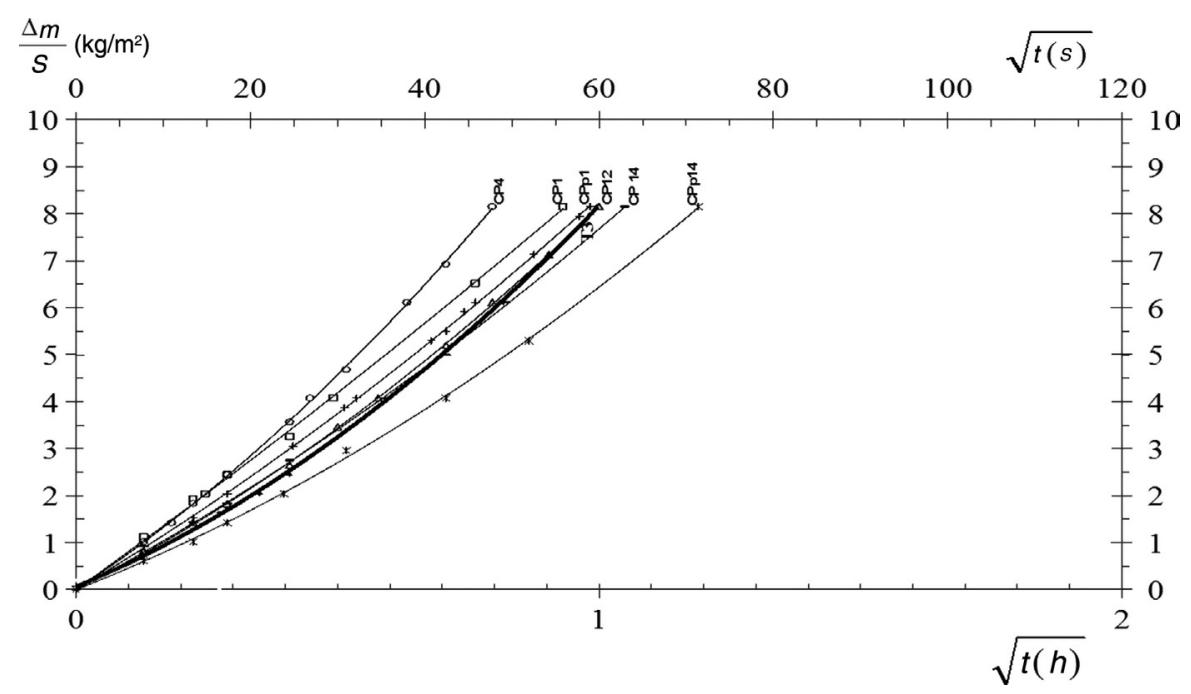

FIGURE 12.5 Water absorption under low-pressure (pipe method) curves.

Obtained on C sandstone specimens and on monument block (T3 test). 


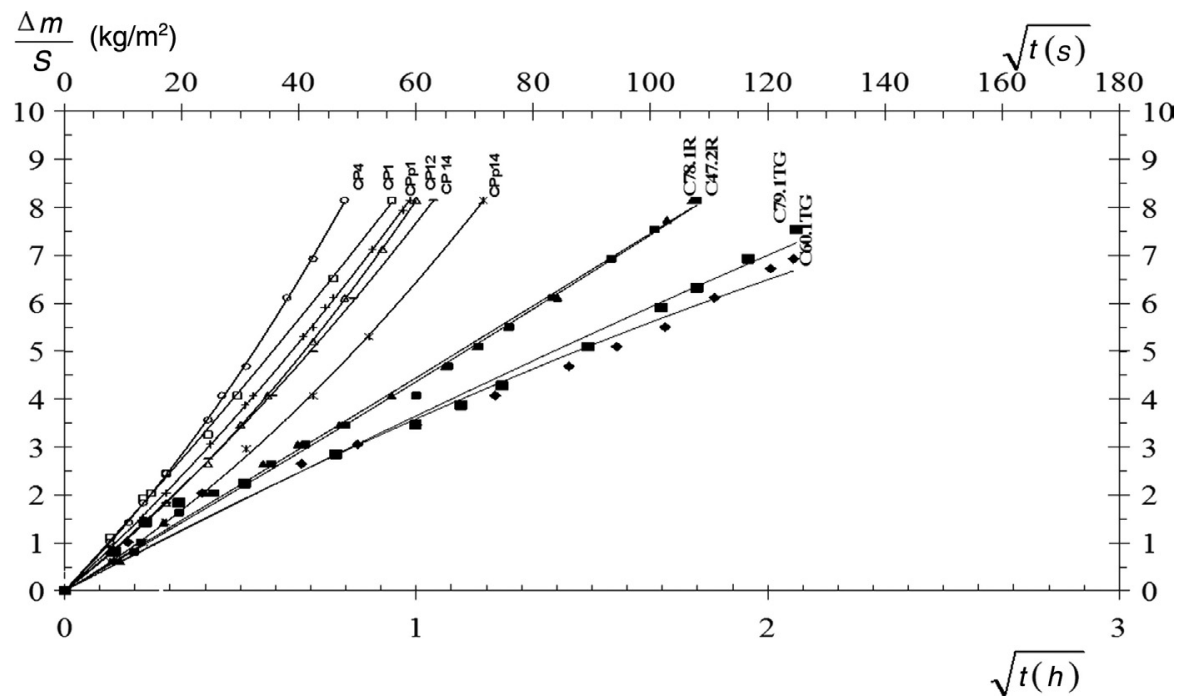

FIGURE 12.6 Water absorption under low-pressure (pipe method) curves.

Obtained on $\mathrm{C}$ sandstone specimens before (empty smaller dots) and after (full larger dots) treatments.

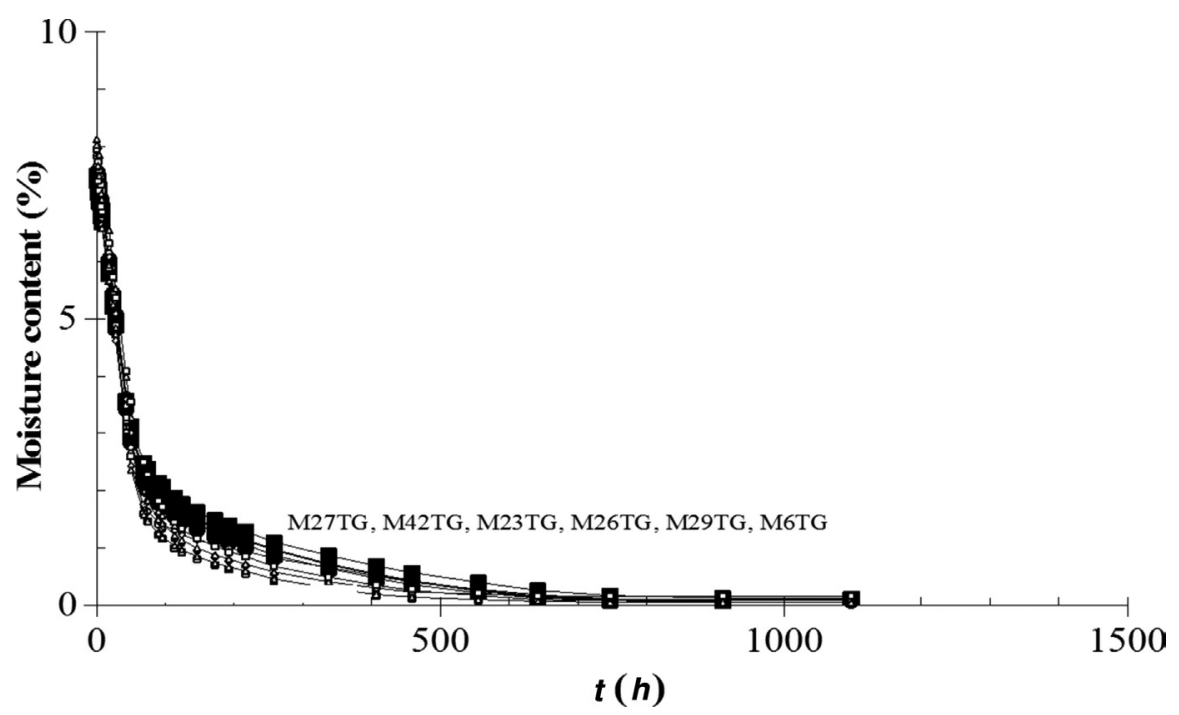

FIGURE 12.7 Drying tests on cubic specimens of M variety.

Before (empty smaller dots) and after treatments with TG (full larger dots). 


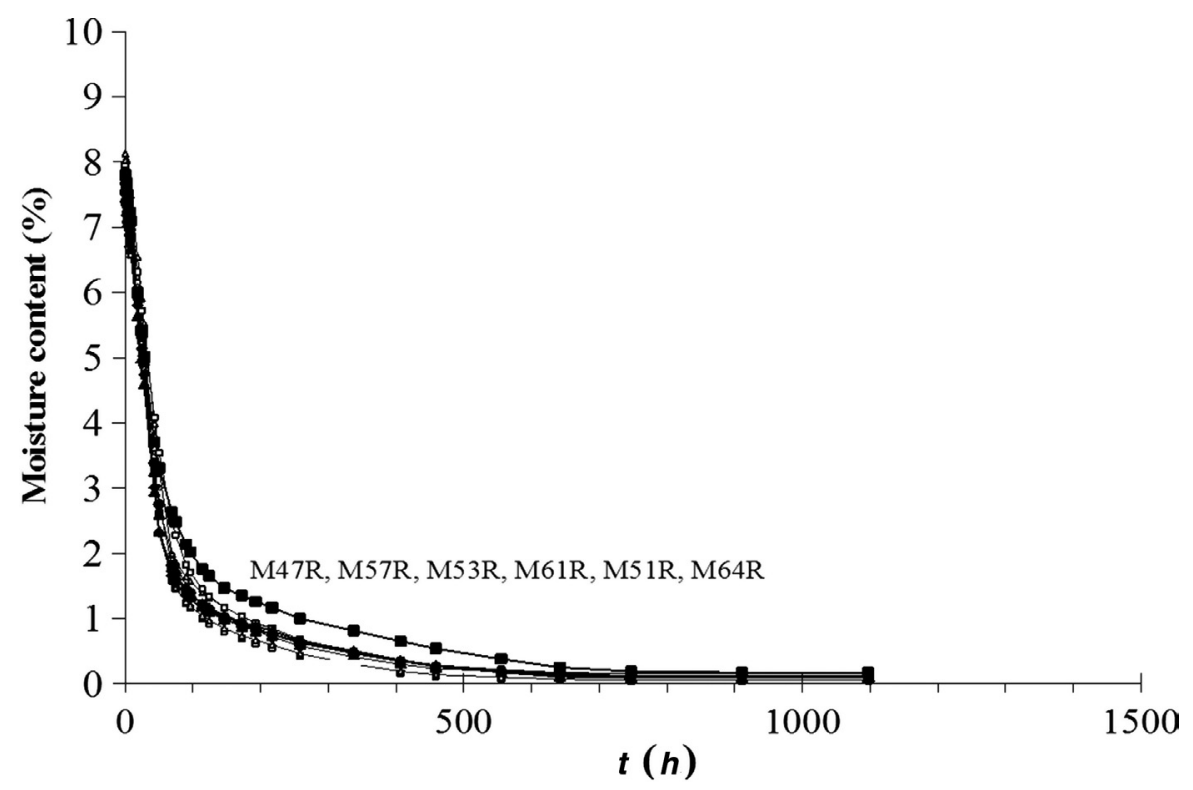

FIGURE 12.8 Drying tests on cubic specimens of $M$ variety.

Before (empty smaller dots) and after treatments with $\mathrm{R}$ (full larger dots).

Table 12.4 Drying Index Values Obtained on Treated and Nontreated M Sandstone Specimens

\begin{tabular}{l|l|l|l}
$\begin{array}{l}\text { Consolidating } \\
\text { Product }\end{array}$ & $\begin{array}{l}\text { Specimens } \\
\text { (cubes) }\end{array}$ & \multicolumn{2}{|c}{ Drying Index Average \pm SD (CV \%) } \\
\hline NT & M & $0.10 \pm 0.01(9.80)$ & \\
& M23 & 0.13 & \\
TG & M27 & 0.12 & \multirow{2}{*}{$0.12 \pm 0.01(8.33)$} \\
& M29 & 0.10 & \\
M6 & 0.13 & \\
R42 & 0.12 & \\
& M26 & 0.12 & \\
& M57 & 0.11 & \\
M53 & 0.11 & \\
\hline
\end{tabular}




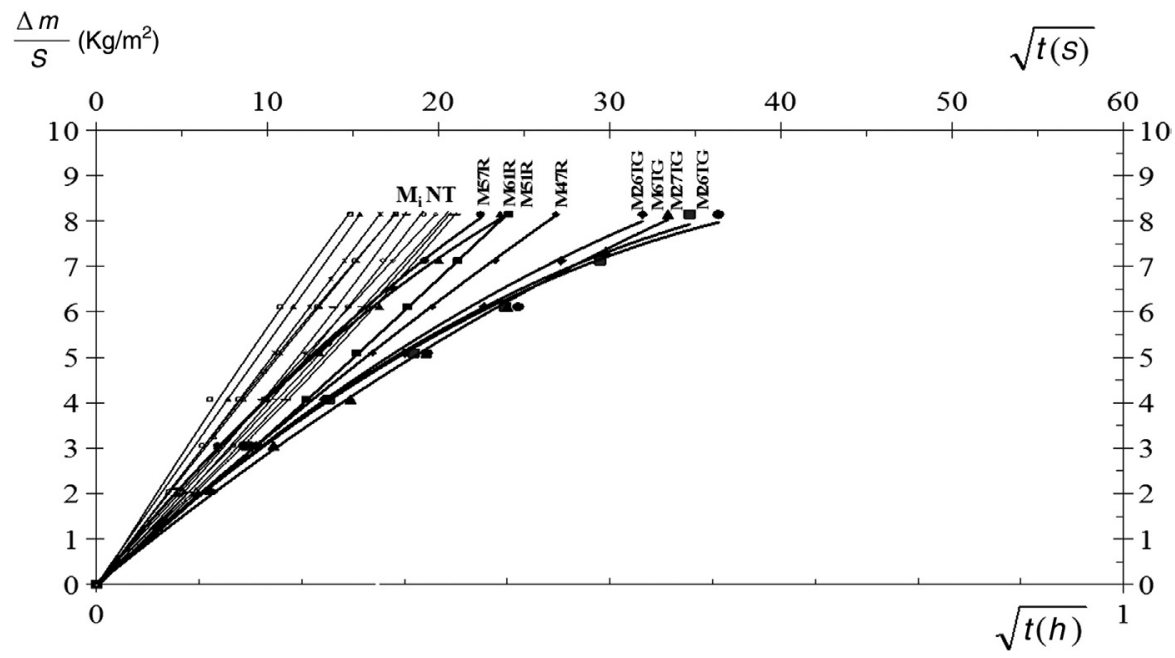

FIGURE 12.9 Water absorption under low pressure (pipe method) curves.

Obtained on $\mathrm{M}$ sandstone specimens before (empty smaller dots) and after (full larger dots) treatments.

Table 12.5 Values of Water Absorption Coefficient $k$ Obtained on Treated and on Nontreated M Sandstone Specimens

\begin{tabular}{|c|c|c|c|}
\hline $\begin{array}{l}\text { Consolidating } \\
\text { Product }\end{array}$ & $\begin{array}{l}\text { Specimens } \\
\text { (cubes) }\end{array}$ & $\begin{array}{l}\text { Water Absorption } \\
\text { Coefficient, } k \\
\left(\mathrm{~kg} / \mathrm{m}^{2} / \sqrt{\mathrm{h}}\right)\end{array}$ & $\begin{array}{l}\text { Water Absorption } \\
\text { Coefficient, } \boldsymbol{k}\left(\mathrm{kg} / \mathrm{m}^{2} / \sqrt{\mathrm{h}}\right)- \\
\text { Average } \pm \mathrm{SD}(\mathrm{CV} \%)\end{array}$ \\
\hline NT & $\begin{array}{l}\text { MP1 } \\
\text { MP2 } \\
\text { MP3 } \\
\text { MP4 } \\
\text { MP5 } \\
\text { M6 }\end{array}$ & $\begin{array}{l}26.4 \\
23.7 \\
22.8 \\
23.2 \\
31.8^{\star} \\
13.3\end{array}$ & $\begin{array}{l}25.6 \pm 3.8(14.7)^{\star} \\
24.0 \pm 1.6(6.8)\end{array}$ \\
\hline TG & $\begin{array}{l}\text { M26 } \\
\text { M27 } \\
\text { M42 }\end{array}$ & $\begin{array}{l}13.6 \\
12.1 \\
11.4\end{array}$ & $12.6 \pm 1.0(8.2)$ \\
\hline $\mathrm{R}$ & $\begin{array}{l}\text { M47 } \\
\text { M51 } \\
\text { M57 } \\
\text { M61 }\end{array}$ & $\begin{array}{l}18.6 \\
20.2 \\
22.7 \\
22.0\end{array}$ & $20.9 \pm 1.9(8.8)$ \\
\hline
\end{tabular}

*With the higher value. 
Table 12.6 Monotonic Uniaxial Compressive Strength $\left(\sigma_{\mathrm{c}}\right)$ Before and After Consolidation Treatments with TG and R

\begin{tabular}{|c|c|c|c|}
\hline Variety & Specimens (cubes) & $\sigma_{\mathrm{c}}(\mathrm{MPa})$ & $\sigma_{\mathrm{c}}(\mathrm{MPa})-$ Average $\pm \mathrm{SD}(\mathrm{CV} \%)$ \\
\hline C & $\begin{array}{l}\text { C18.1 } \\
\text { C24.1 } \\
\text { C60.2 } \\
\text { C79.2 } \\
\text { C87.1 }\end{array}$ & $\begin{array}{l}51.2 \\
61.7 \\
53.5 \\
59.1 \\
61.9\end{array}$ & $57.5 \pm 4.9(8.5)$ \\
\hline $\mathrm{TG}$ & $\begin{array}{l}\text { C21 } \\
\text { C22 } \\
\text { C23 } \\
\text { C47.1 }\end{array}$ & $\begin{array}{l}76.5 \\
68.6 \\
66.5 \\
77.3\end{array}$ & $72.2 \pm 5.5(7.6)$ \\
\hline $\mathrm{R}$ & $\begin{array}{l}\text { C19.2 } \\
\text { C21.2 } \\
\text { C20 }\end{array}$ & $\begin{array}{l}60.5 \\
66.3 \\
68.2\end{array}$ & $63.2 \pm 2.9(4.6)$ \\
\hline
\end{tabular}

\subsection{MECHANICAL BEHAVIOR}

The monotonic uniaxial compressive strength $\left(\sigma_{\mathrm{c}}\right)$ values before consolidation treatments and after applications with $\mathrm{TG}$ and $\mathrm{R}$ on $\mathrm{C}$ variety of sandstone specimens indicate a clear increment of about $26 \%$ on TG and $10 \%$ on R treatments (Table 12.6).

The comparison between the monotonic uniaxial compressive strength $\left(\sigma_{\mathrm{c}}\right)$ values of treated and nontreated specimens of sandstone $M$ variety show an increase of about $56 \%$ on TG and around $16 \%-22 \%$ on R treatments.

The average values of drilling strength on $\mathrm{C}$ sandstone are about $1.3 \mathrm{MPa}$. They increased from $0.5 \mathrm{MPa}$ on $\mathrm{M}$ sandstone to $0.6 \mathrm{MPa}$ on $\mathrm{R}$ applications and to $0.7 \mathrm{MPa}$ on TG applications. The drilling depth reached at least $15 \mathrm{~mm}$, length enough to obtain average strength values.

\subsection{DURABILITY ASSESSMENT TESTS}

Salt-weathering research was responsible for the production of 1800 articles up to the beginning of the 21 st century [4]. Nowadays, this research is ongoing on nontreated natural stones [15-22] and on bricks [23]. Chen et al. [17] and Ruffolo et al. [22] studied also salt weathering effect on treated stones with consolidating products.

In the present chapter, Fig. 12.10 shows the percentage of sandstone's variation of mass loss ratio under salt crystallization artificial aging tests on treated and not treated $\mathrm{M}$ sandstone variety. After 60 salt cycles, the average mass loss of nontreated sandstone samples was about $8 \%$.

After 30 salt cycles the average mass loss of sandstone samples with consolidation applications have a reduction of $50 \%$ from an average value of $3 \%$ on nontreated specimens to about $1.5 \%$ of treated specimens. After 60 salt cycles the variation of mass loss ratio is higher on treated specimens with TG than on nontreated specimens, ranging between circa $3 \%$ and $15 \%$ with an average value of circa $9 \%$. After 70 salt 


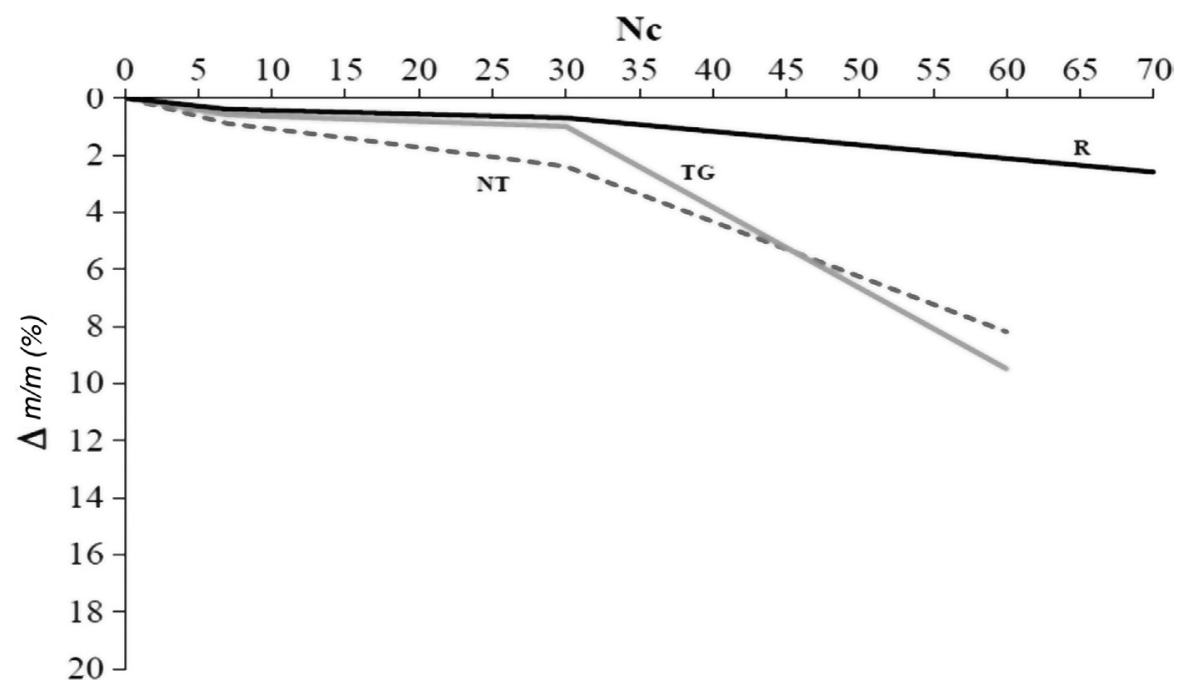

FIGURE 12.10 Loss mass ratio $(\Delta m / m)$ during salt-crystallization aging cycles (Nc).

Carried out on nontreated samples (NT: dashed line) and consolidated sandstone samples with TG (light gray line) and R (black line).

cycles on treated specimens with $\mathrm{R}$ the variation of mass loss ratio is less than on nontreated specimens, around a mean value of $3 \%$.

The water absorption under low-pressure curves of M specimens under salt-crystallization artificial aging is shown in Fig. 12.11. After 30 salt cycles on nontreated samples the average values of coefficient of absorption are similar to $\mathrm{R}$ specimens after 70 salt cycles, that is, $22 \mathrm{~kg} / \mathrm{m}^{2} / \sqrt{\mathrm{h}}$. An average value of coefficient of absorption on TG specimens after 30 salt cycles is about $13 \mathrm{~kg} / \mathrm{m}^{2} / \mathrm{Vh}$, that is, a decrease of about $40 \%$ in comparison to nontreated specimens after the same number of salt cycles.

The compressive strength of nontreated $\mathrm{M}$ specimens decreased about $56 \%$ during 60 cycles of accelerated salt crystallization and TG treated specimens have an average reduction of circa $75 \%$, whereas sandstone specimens treated with $\mathrm{R}$ have a minor reduction of about $18 \%$ at the 70 th cycle in comparison to the initial values of nontreated specimens (Fig. 12.12).

The regression equations in Fig. 12.12 allow extrapolation of data for more than 60 or even 120 cycles, being predictive of the compressive behavior of sandstone specimens before and after treatments with consolidating products.

The compressive strength data of nontreated specimens in Fig. 12.12, when it is extrapolated for more than 100 cycles decreased to about $30 \%$ of the initial values. At the 115 th cycle, the compressive strength should be less than $30 \%$ of its value before salt aging, being higher than its value on $\mathrm{R}$ treated specimens that is null.

The results of drilling strength average values obtained on a monumental block with a porosity value similar to $\mathrm{M}$ variety are given in Fig. 12.13. It shows a decrease from 1.1 to $0.8 \mathrm{MPa}$, circa $27 \%$ and is due to salt-crystallization natural aging. The weathering thickness is about $8 \mathrm{~mm}$ under the surface of the block. 


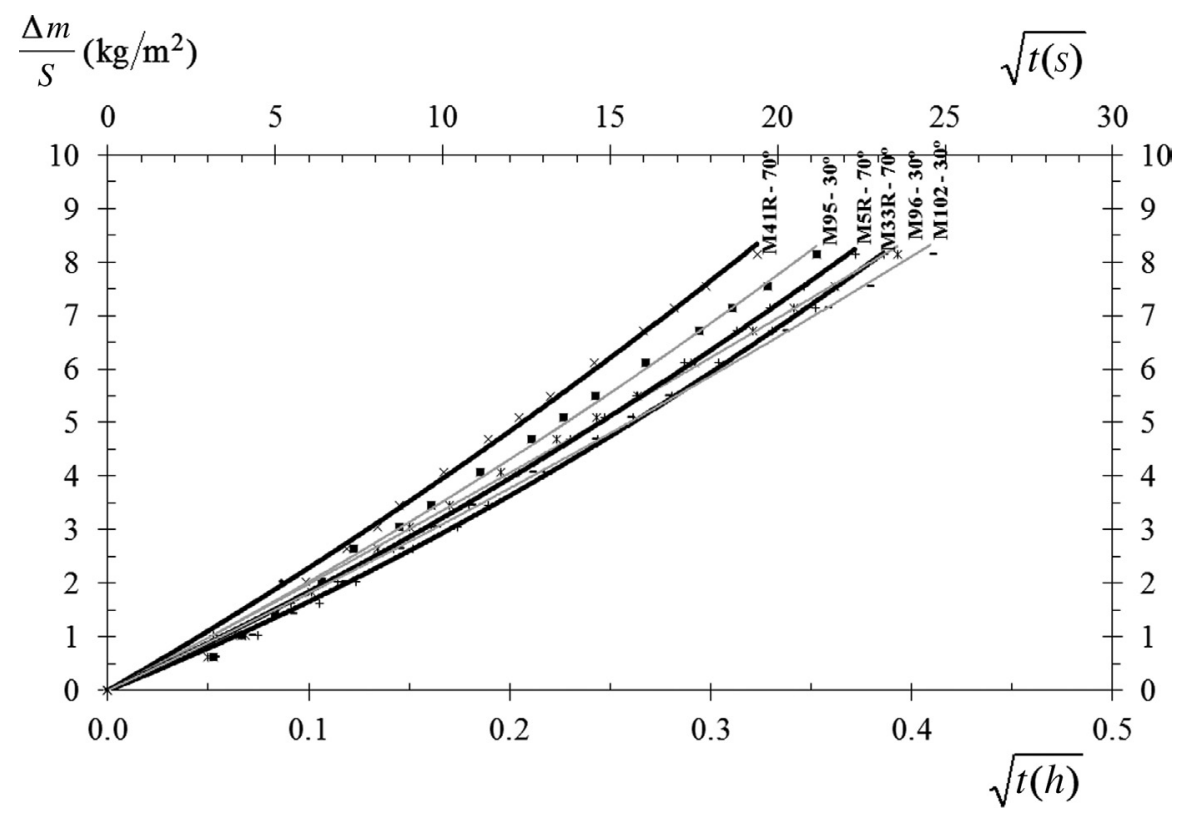

FIGURE 12.11 The water absorption under low pressure (pipe method) curves.

Obtained on M sandstone specimens without treatment (light gray lines) after 30 salt cycles and treated with R (black lines) after 70 salt cycles.

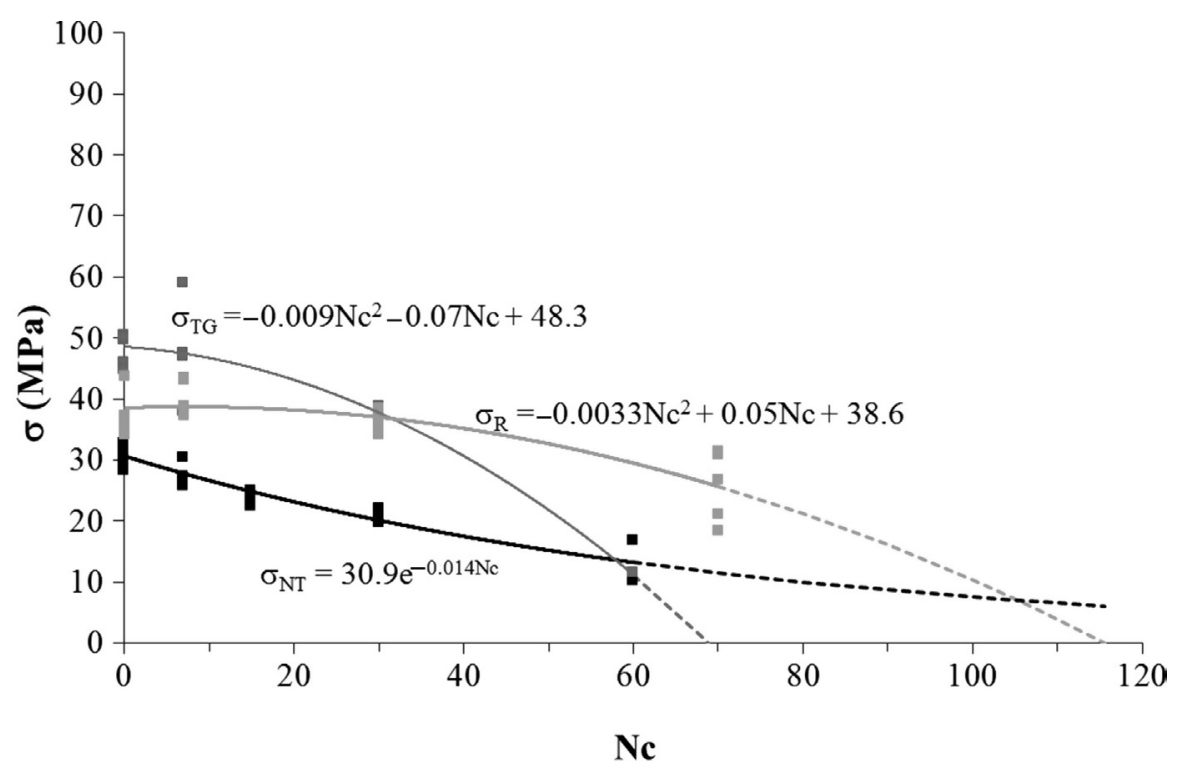

FIGURE 12.12 The compressive strength of sandstone specimens.

Nontreated (black squares) and treated with ethyl silicates TG (dark gray squares) and R (light gray squares) during salt crystallization artificial aging tests. 


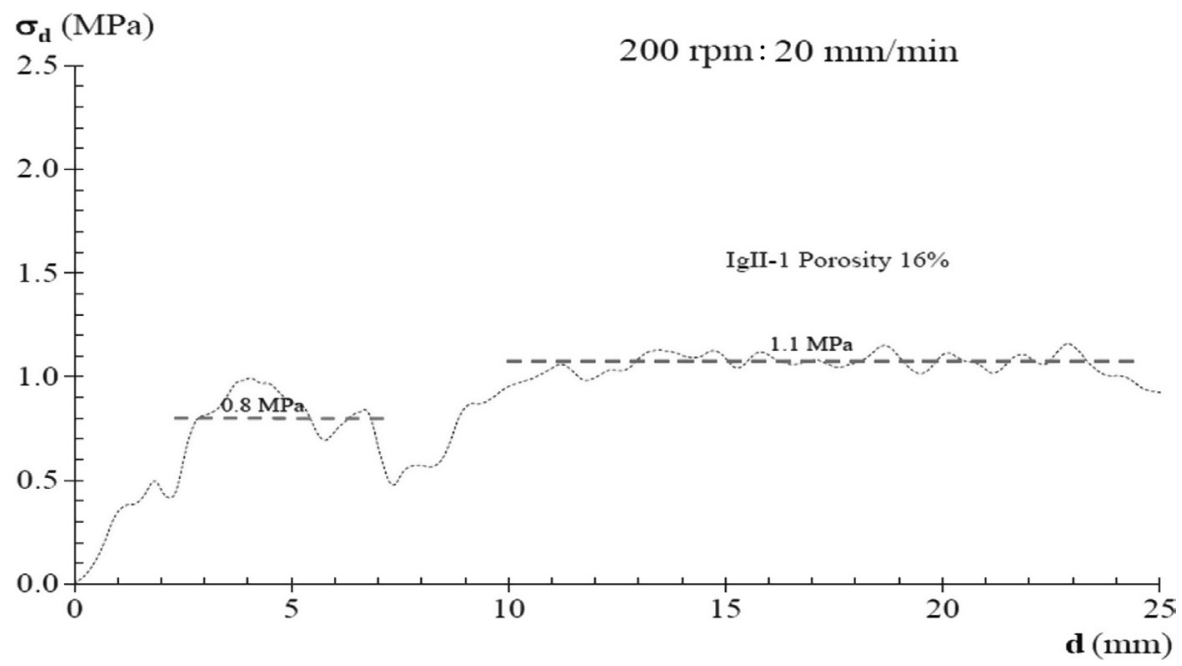

FIGURE 12.13 Drilling strength profile.

Obtained without tip wear on a monument block with $16 \%$ of porosity; shows the difference between sound and weathered stone.

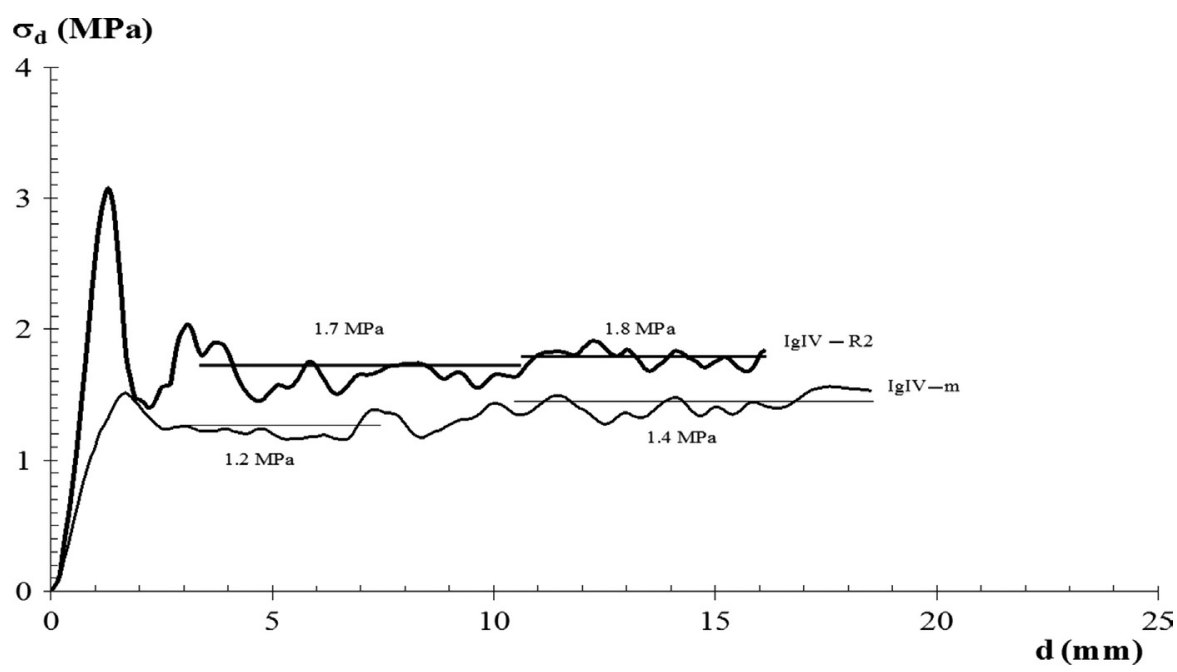

FIGURE 12.14 Drilling strength profiles.

Obtained without tip wear on monument block before (mean profile of IGIV 1, IGIV 2, IGIV 3) and after consolidation treatments with R (R2).

The drilling strength average values obtained on a monumental block with a porosity value similar to $\mathrm{C}$ variety are given in Figs. 12.14 and 12.15.These mean values increased from 1.2 to $1.4 \mathrm{MPa}$ on $\mathrm{C}$ sandstone to $1.7-2.0 \mathrm{MPa}$ on $\mathrm{R}$ applications. The drilling depths reached up to $20 \mathrm{~mm}$, deep enough to obtain average strength values and identify the impregnation thickness higher than $15 \mathrm{~mm}$. 


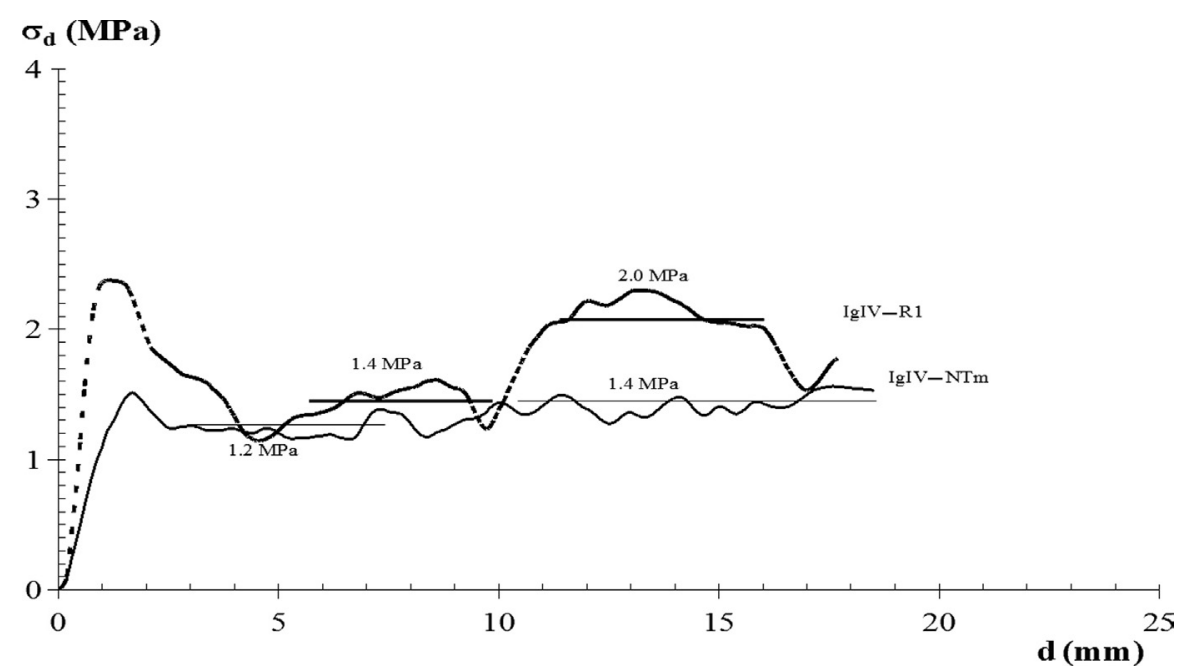

FIGURE 12.15 Drilling strength profiles.

Obtained without tip wear on monument block before (mean profile of IGIV 1, IGIV 2, IGIV 3) and after consolidation treatments with R (R1).

\section{CONCLUSIONS}

A Karsten pipe using total head to allow full absorption of consolidating products on sandstone facades was used in conservation treatments.

On $\mathrm{C}$ and $\mathrm{M}$ sandstone specimens, two ethyl silicates (TG and $\mathrm{R}$ ) were applied. The experimental study of physical and mechanical behavior in the laboratory revealed minor harmful characteristics of the $\mathrm{R}$ applications on $\mathrm{M}$ variety of sandstones, in comparison with $\mathrm{C}$ variety, and a better consolidation effect of TG on both varieties.

The salt-crystallization artificial aging tests highlighted good durability of $\mathrm{R}$ applications and a worst behavior of TG treatments. M sandstone specimens treated with $\mathrm{R}$ have a minor reduction of compressive strength of about $18 \%$ in comparison to the initial values of nontreated specimens at the end of salt-crystallizationdissolution artificial aging tests, whereas TG applications showed lower values in comparison with nontreated weathered specimens.

The regression equations allowed extrapolation data for more than 60 experimental aging cycles carried out, predictive of the compressive behavior of $\mathrm{M}$ sandstone specimens before and after treatments with consolidating products. The good durability effect of $\mathrm{R}$ applications disappeared at the prediction of the 115 th cycle. Its average compressive strength should be null and so, less than $30 \%$ of the value of nontreated specimens before salt aging. The prediction indicates that at the end of the aging procedure, the remaining strength of the nontreated specimens is higher than of the treated specimens. However, this remaining strength of the nontreated specimens is not enough to assure mechanical stability. 
In spite of $\mathrm{R}$ lower consolidation effect on sandstone $\mathrm{C}$ and $\mathrm{M}$ varieties in comparison with $\mathrm{TG}$, the less harmful effect and better salt crystallization-dissolution artificial aging behavior of the former in the laboratory allowed its selection as the more suitable treatment to apply on the monument's sandstone varieties.

The consolidation effect assessed by drilling strength values obtained on sandstone C variety of masonry's monument showed an increase of more than $40 \%$ after $\mathrm{R}$ ethyl silicate applications and an impregnation thickness higher than $15 \mathrm{~mm}$.

The comparison between immersion-based procedure applications and the Karsten pipe's method on stone monuments indicates the potential viability of this new approach to obtain a good consolidation effect when difficult conditions of absorption occur.

\section{REFERENCES}

[1] International Council on Monuments and Sites/International Scientific Committee for Stone (ICOMOS-ISCS), Illustrated glossary on stone deterioration patterns, September 2008.

[2] M. Ludovico-Marques, Contribution to the knowledge of the effect of crystallization of salts in the weathering of sandstones: application to the built heritage of Atouguia da Baleia, PhD thesis in Geotechnical Engineering, specializing in Rock Mechanics, Universidade NOVA de Lisboa, Lisbon, 2008 (in Portuguese).

[3] F. Zezza, Inland dispersion of marine spray and its effects on monument stone, in: Proceedings of 5th International Symposium on the Conservation of Monuments in the Mediterranean Basin, Sevilla, 2002, pp. 23-39.

[4] E. Doehne, Salt weathering: a selective review, Natural Stone, Weathering Phenomena, Conservation Strategies and Case Studies, vol. 205, Geological Society of London, Special Publications, London, (2002) pp. 51-64.

[5] I. Evans, Salt crystallization and rock weathering: a review, Rev. Geomorphol. Dynam. XIX (4) (1970) 153-177.

[6] S. Bates, A critical evaluation of salt weathering impacts on building materials at Jazirat al Hamra, UAE, Geoverse, 2010. ISSN 1758-3411, 1-17.

[7] M. Ludovico-Marques, C. Chastre, Effect of salt crystallization ageing on the compressive behavior of sandstone blocks in historical buildings, Eng. Fail. Anal. 26 (2012) 247-257.

[8] C. Rodriguez-Navarro, E. Dohene, E. Sebastian, Origins of honeycomb weathering: the role of salts and wind, Bull. Geol. Soc. Am. 111 (1999) 1250-1255.

[9] RILEMRecommended tests to measure the deterioration of stone and to assess the effectiveness of treatment methods, Mater. Struct. 13 (75) (1980) 175-253 Bourdais-Dunoud.

[10] R. Folk, Petrology of Sedimentary Rocks, Hemphill Publishing, Austin, TX, (1974).

[11] EN 1936. Natural stone test method-determination of real density and apparent density, and of total and open porosity, European Standard, 1999.

[12] F. Pellerin, La Porosimetrie au Mercure Appliquee a 1 Etude Geotechnique des Sols et des Roches, Bull. Liaison Lab. Ponts Chaussés 106 (1980) 105-116.

[13] NORMAL-29/88, Misura dell' Indice di Asciugamento (Drying Index), Alterazioni dei Material Lapidei e Trattamenti Conservativi-Proposte per l'Unificazione dei Metodi Sperimentali di Studio e di Controllo, CNR-ICR, Rome, Italy, 1991. 


\section{CHAPTER 12 Consolidation works on sandstone monuments}

[14] NP EN 12370, Métodos de ensaio para pedra natural, Determinação da resistência à cristalização de sais, Instituto Português da Qualidade 2002, p. 10 [in Portuguese].

[15] G. Barone, P. Mazzoleni, G. Pappalardo, S. Raneri, Microtextural and microstructural influence on the changes of physical and mechanical proprieties related to salts crystallization weathering in natural building stones: the example of Sabucina stone (Sicily), Constr. Build. Mater. 95 (2015) 355-365.

[16] A. Al-Omari, K. Beck, X. Brunetaud, M. Al-Mukhtar, Weathering of limestone on AlZiggurat walls in the ancient Al-Nimrud city (Iraq), Environ. Earth Sci. 74 (2015) 609620 .

[17] W. Chen, P. Dai, P. Yuan, J. Zhang, Effect of inorganic silicate consolidation on the mechanical and durability performance of sandstone used in historical sites, Construct. Build. Mater. 121 (2016) 445-452.

[18] M. Ludovico-Marques, C. Chastre, Effect of artificial accelerated salt weathering on physical and mechanical behaviour of sandstone samples from surface reservoirs, in: A.S. Hamdy Makhlouf, M. Aliofkhazraei (Eds.), Handbook of Materials Failure Analysis With Case Studies from the Oil and Gas Industry, Elsevier, 2016, pp. 215-233.

[19] M. Heidari, M. Torabi-Kaveh, C. Chastre, M. Ludovico-Marques, H. Mohseni, H. Akefi, Determination of weathering degree of the Persepolis stone under laboratory and natural conditions using fuzzy inference system, Construct. Build. Mater. 145 (2017) 28-41.

[20] M. Heidari, C. Chastre, M. Torabi-Kaveh, M. Ludovico-Marques, H. Mohseni, Application of fuzzy inference system for determining weathering degree of some monument stones in Iran, J. Cult. Herit. 25 (2017) 41-55.

[21] H. Özşen, A. Bozdağ, İ. İnce, Effect of salt crystallization on weathering of pyroclastic rocks from Cappadocia, Turkey, Arabian J. Geosci. 10 (258) (2017) 1-8.

[22] S. Ruffolo, M. La Russa, M. Ricca, C. Belfiore, A. Macchia, V. Comite, A. Pezzino, G. Crisci, New insights on the consolidation of salt weathered limestone: the case study of Modica stone, Bull. Eng. Geol. Environ. 76 (2017) 11-20.

[23] Paolo Foraboschi, Alessia Vanin, Experimental investigation on bricks from historical Venetian buildings subjected to moisture and salt crystallization, Eng. Fail. Anal. 45 (2014) 185-203. 